\title{
TURINYS / CONTENTS / COДEPЖAНИЕ
}

\author{
MIELI SKAITYTOJAI / DEAR READERS / УВАЖАЕМЫЕ ЧИТАTЕЛИ
}

Lamanauskas V. Vadyba: atsakomybės aspektas 4

\section{MOKSLINIAI STRAIPSNIAI / SCIENTIFIC ARTICLES / HAУЧHЫE CTATЬИ}

Lamanauskas V., Augienė D., Makarskaitė-Petkevičienė R. Universitetinių studijų problematika studentų požiūriu: privalumai ir trūkumai 7

METODINIAI STRAIPSNIAI / METHODICAL ARTICLES / МЕTOДИЧЕСКИЕ СТАТЬИ

Bilbokaitė R. Studentų poreikiai praktikos kokybei: privalumai ir trūkumai 19

UŽSIENIO EDUKACINE் PATIRTIS / FOREIGN EDUCATIONAL EXPERIENCE / ЗАРУБЕЖНЫЙ ОПЫТ ОБРАЗОВАНИЯ

Akhmetov M. Chemistry Web Education: Improving of Users` Learning Activities 26

INTERVIU / INTERVIEW / ИHTEPBЬЮ

Stankutė J. Kaimo mokyklos godos 35

\section{KRONIKA / CRONICLE / КPOHИКA}

Vizualizacijos taikymo gamtamoksliniame ugdyme psichoedukaciniai veiksniai 38

\section{INFORMACIJA / INFORMATION / ИНФОРМАЦИЯ}

Informacija autoriams / Instructions for Authors 40

Tarptautinis mokslinis metodinis žurnalas „Gamtamokslinis ugdymas“ /

„Natural Science Education“ 41

Problems of Education in the 21st Century 42

Problems of Management in the 21st Century 43

Problems of Psychology in the 21st Century 